\title{
METODE GENERALIZED MEAN DISTANCE-BASED K-NEAREST NEIGHBOR CLASSIFIER (GMDKNN) UNTUK ANALISIS CREDIT SCORING CALON DEBITUR KREDIT TANPA AGUNAN (KTA)
}

\author{
Mei Sita Saraswati ${ }^{1}$, Moch. Abdul Mukid ${ }^{2}$, Abdul Hoyyi ${ }^{3}$ \\ ${ }^{1}$ Mahasiswa Departemen Statistika FSM Universitas Diponegoro \\ ${ }^{2,3}$ Dosen Departemen Statistika FSM Universitas Diponegoro \\ meisitasaras@gmail.com
}

\begin{abstract}
Unsecured Credit is one of the credit facilities provided by banks, where the prospective debtor can borrow some amount of fund from the bank without having to provide collateral. Credit scoring is a process that aims to assess the worthiness of credit applications and classify the credit applicants into prospective debtors whose the credit application is worthy to be accepted and prospective debtors whose the credit application should be rejected. One of the statistical methods that can be applied in examining the analysis of credit scoring is the Generalized Mean Distance-Based k-Nearest Neighbor (GMDKNN) classifier. Empirical study on this method uses 23,337 data of prospective debtor of unsecured credit in 2018, with the dependent variable being the credit scoring final decision and seven independent variables, i.e. age, child dependent, length of employment, age of the company, income, loan proposed, and duration of credit. Based on the feature selection test, all independent variables are significantly taking effect on the credit scoring final decision. The best classification model is obtained in the parameters $\mathrm{k}=137$ and $\mathrm{p}=-1$ with the classification performance metrics represented by the values of APER $=0,2580$, accuracy $=$ $74,20 \%$, sensitivity $=0,6083$, specificity $=0,8393, \mathrm{AUC}=0,7238$, and G-Mean $=0,7146$.
\end{abstract}

Keywords: Unsecured Credit, credit scoring, classification, Generalized Mean DistanceBased k-Nearest Neighbor (GMDKNN).

\section{PENDAHULUAN}

Perkreditan bagi masyarakat perseorangan atau badan usaha adalah salah satu kegiatan usaha bank dalam rangka penyaluran dan penghimpunan dana. Menurut Rama dan Jones (2009), kredit merupakan sumber utama bank dalam menjalankan aktivitas usahanya termasuk pada perusahaan pembiayaan. Pemberian kredit, selain sebagai aktiva produktif terbesar suatu bank juga merupakan pembawa risiko tertinggi yang mampu mempengaruhi tingkat kesehatan bank (Firdaus \& Ariyanti, 2009). Salah satu risiko dari aktivitas penyaluran kredit oleh bank yaitu munculnya kredit bermasalah atau yang sering disebut dengan kredit macet. Kredit macet merupakan suatu keadaan dimana debitur baik perorangan atau perusahaan tidak mampu membayar kredit bank tepat pada waktunya sehingga mengancam likuiditas bank tersebut.

Salah satu jenis kredit yang disalurkan oleh bank adalah Kredit Tanpa Agunan (KTA). KTA adalah sebuah produk bank, dimana calon debitur dapat meminjam sejumlah dana atau uang dari bank tanpa harus memberikan jaminan atau agunan, sehingga KTA memiliki risiko lebih terhadap penyelewengan kredit pinjaman oleh debitur dibandingkan jenis kredit lainnya.

Kebanyakan perbankan telah menerapkan prosedur credit scoring untuk menilai risiko berkaitan dengan pinjaman kepada calon debitur dan mengklasifikasi para pemohon kredit ke dalam dua kelompok yaitu calon debitur yang permohonan kreditnya layak untuk diterima dan calon debitur yang permohonan kreditnya sebaiknya ditolak. Untuk melaksanakan 
proses credit scoring, telah diaplikasikan metode statistika yaitu bermacam teknik klasifikasi.

Metode klasifikasi yang baik adalah metode yang menghasilkan kesalahan yang kecil (Johnson \& Wichern, 2007). Saat ini terdapat banyak metode statistika yang digunakan untuk mengklasifikasi, salah satunya adalah metode Generalized Mean Distance-Based kNearest Neighbor (GMDKNN). Menurut Gou et al. (2019), metode GMDKNN merupakan pengembangan dari metode k-Nearest Neighbor (KNN) dengan memperkenalkan multigeneralized mean distances dan nested generalized mean distance yang keduanya didasarkan pada karakteristik rata-rata tergeneralisasi. Berdasarkan hasil penelitian sebelumnya oleh Gou et al. (2019), diperoleh kesimpulan bahwa metode GMDKNN dapat meningkatkan performa klasifikasi berbasis KNN serta mampu mengatasi sensitivitas dari tetangga ukuran $k$ yang seringkali secara signifikan menurunkan performa klasifikasi berbasis KNN. Maka dalam penulisan ini akan diterapkan metode GMDKNN untuk mengklasifikasikan keputusan akhir permohonan kredit calon debitur KTA pada proses credit scoring Bank " $\mathrm{X}$ ".

\section{TINJAUAN PUSTAKA}

\subsection{Kredit}

Menurut Undang-Undang Perbankan nomor 10 tahun 1998 pengertian kredit adalah penyediaan uang atau tagihan yang dapat dipersamakan dengan itu, berdasarkan persetujuan atau kesepakatan pinjam meminjam antara bank dengan pihak lain yang mewajibkan pihak peminjam melunasi utangnya setelah jangka waktu tertentu dengan pemberian bunga. Menurut Sinungan (1991) tujuan utama pemberian kredit adalah untuk memperoleh keuntungan dalam bentuk bunga yang diterima oleh bank sebagai balas jasa dan biaya administrasi kredit yang dibebankan kepada nasabah.

\subsection{Credit scoring}

Credit scoring didefinisikan sebagai sebuah metode sistematis untuk mengevaluasi risiko kredit yang menyajikan suatu analisis konsisten dari faktor-faktor yang telah ditetapkan sebelumnya sebagai penyebab atau mempengaruhi level dari risiko (Fensterstock, 2005). Credit scoring membantu menentukan apakah kredit seharusnya diberikan kepada peminjam atau tidak (Morrison, 2004). Teknik yang paling umum digunakan dalam pembentukan model credit scoring adalah metode statistika yaitu klasifikasi.

\subsection{Data Mining}

Turban et al. (2005) mendefinisikan data mining sebagai proses menggunakan teknik statistika, matematika, kecerdasan buatan, dan machine learning untuk mengekstraksi dan mengidentifikasi informasi yang bermanfaat dan pengetahuan yang terkait dari berbagai database besar. Tahapan data mining menurut Jiawei (2006) meliputi data cleaning, data integration, data selection, data transformation, data mining, pattern evaluation, dan knowledge presentation. Berdasarkan tugasnya, data mining dikelompokkan menjadi deskripsi, estimasi, prediksi, klasifikasi, clustering, dan asosiasi (Larose, 2005).

\subsection{Seleksi Fitur}

Langkah yang paling sederhana dalam memilih fitur adalah mengamati setiap fitur yang dibangkitkan secara independen dan menguji kemampuan diskriminasinya pada masalah yang harus diselesaikan (Prasetyo, 2014). Untuk tujuan tersebut, dapat diterapkan prosedur nonparametrik yaitu uji Mann-Whitney.

Penjelasan uji Mann-Whitney oleh Conover (1980) yaitu pada data yang terdiri dari dua sampel acak, dimana $\mathbf{x}_{1}, \mathbf{x}_{2}, \ldots, \mathbf{x}_{\mathrm{n} 1}$ menotasikan sampel acak sebanyak $\mathrm{n}_{1}$ dari populasi 
1 dan $\mathbf{y}_{1}, \mathbf{y}_{2}, \ldots, \mathbf{y}_{\mathrm{n} 2}$ menotasikan sampel acak sebanyak $\mathrm{n}_{2}$ dari populasi 2 , kemudian ditentukan peringkat 1 hingga $\mathrm{n}_{1}+\mathrm{n}_{2}$ untuk semua sampel data. Tahapan pengujian dijelaskan oleh Daniel (1989) yang diawali dengan penetapan hipotesis nol sebagai nilai ratarata fitur dalam dua kelas sama dan hipotesis alternatifnya yaitu nilai rata-rata fitur dalam dua kelas berbeda. Selanjutnya dihitung statistik uji dengan rumus:

$$
T=S-\frac{n_{1}\left(n_{1}+1\right)}{2}
$$

dengan $S$ adalah jumlah peringkat hasil-hasil pengamatan yang merupakan sampel dari populasi 1. Apabila entah $n_{1}$ atau $n_{2}$ lebih besar dari 20, maka teorema limit sentral dapat diterapkan, dengan demikian statistik uji:

$$
Z=\frac{T-n_{1} n_{2} / 2}{\sqrt{\frac{n_{1} n_{2}\left(n_{1}+n_{2}+1\right)}{12}-\frac{n_{1} n_{2}\left(\sum t^{3}-\sum t\right)}{12\left(n_{1}+n_{2}\right)\left(n_{1}+n_{2}-1\right)}}}
$$

dengan $\mathrm{t}$ adalah banyaknya angka sama untuk suatu peringkat. Kriteria uji yaitu $\mathrm{H}_{0}$ ditolak jika $Z>Z_{\alpha / 2}$ atau $Z<-Z_{\alpha / 2}$ atau apabila p-value $<\alpha$, dimana $Z_{\alpha / 2}$ adalah nilai kritis yang diperoleh dari tabel distribusi normal standar.

\subsection{Standarisasi Data}

Untuk mencegah pengaruh perbedaan satuan antar atribut terhadap analisa data, dilakukan standarisasi terhadap nilai atribut (Larose, 2005). Salah satu metode standarisasi yang umum diterapkan adalah metode $z$-score. Formula untuk standarisasi atribut X dengan metode z-score adalah:

$$
Z=\frac{X-\bar{X}}{s_{X}}
$$

dengan $\mathrm{Z}$ adalah nilai setelah distandarisasi, $X$ adalah nilai sebelum distandarisasi, $\bar{X}$ adalah rata-rata nilai sebelum distandarisasi, $s_{X}$ adalah nilai standar deviasi atribut $X$.

\subsection{Klasifikasi}

Klasifikasi didefinisikan sebagai suatu pekerjaan yang melakukan pelatihan/pembelajaran terhadap fungsi target $\mathrm{f}$ yang memetakan setiap vektor (set fitur) $\mathrm{x}$ ke dalam satu dari sejumlah label kelas y yang tersedia. Pekerjaan pelatihan tersebut akan menghasilkan suatu model yang kemudian disimpan sebagai memori (Prasetyo, 2014). Dalam pembangunan model diperlukan adanya algoritma pelatihan (learning algorithm). Algoritma pelatihan mempunyai prinsip melakukan suatu pelatihan sehingga di akhir pelatihan model dapat memetakan (memprediksi) setiap vektor masukan ke label kelas keluaran dengan benar (Prasetyo, 2014).

\subsection{Jarak Euclid}

Ukuran ketidakmiripan yang paling umum digunakan dalam metode klasifikasi adalah jarak Euclid (Prasetyo, 2014). Jarak Euclid memberikan jarak lurus antara dua buah data $\mathbf{x}_{\boldsymbol{b}}=\left(x_{1 b}, x_{2 b}, \ldots, x_{n b}\right)$ dan $\mathbf{x}_{\boldsymbol{a}}=\left(x_{1 a}, x_{2 a}, \ldots, x_{n a}\right)$ yang diformulasikan oleh persamaan berikut:

$$
\mathrm{d}\left(\mathbf{x}_{\boldsymbol{b}}, \mathbf{x}_{\boldsymbol{a}}\right)=\sqrt{\sum_{l=1}^{n}\left(x_{b l}-x_{a l}\right)^{2}}
$$

dengan d adalah jarak antara data $\mathbf{x}_{\boldsymbol{b}}$ dan $\mathbf{x}_{\boldsymbol{a}}, \mathbf{x}_{\boldsymbol{b}}$ adalah data uji, $\mathbf{x}_{\boldsymbol{a}}$ adalah data latih, dan $\mathrm{n}$ adalah banyaknya fitur (dimensi) data.

\subsection{Generalized Mean Distance-Based $k$-Nearest Neighbor (GMDKNN)}


Gou et al. (2019) memperkenalkan metode Generalized Mean Distance-based kNearest Neighbor Classifier (GMDKNN) sebagai pengembangan dari metode $k$-Nearest Neighbour (KNN) dengan inovasi utama berupa Multi-generalized mean distances berbasis multi-local mean vectors serta Nested generalized mean distance. Gou et al. (2019) mendeskripsikan langkah-langkah untuk memberikan label kelas dari sampel uji $\mathbf{x}$ menggunakan metode GMDKNN, sebagai berikut:

a) Mencari k tetangga terdekat terhadap $\mathbf{x}$ dari himpunan $\mathbf{X}^{\mathbf{j}}$ di setiap kelas $\boldsymbol{\omega}_{j}$, dinyatakan sebagai $\boldsymbol{X}_{j}^{N N}=\left\{\boldsymbol{x}_{i j}^{N N} \in R^{d}\right\}_{i=1}^{k}$. Penentuan $k$ nearest neighbor diurutkan dari tetangga dengan jarak Euclid terdekat hingga tetangga dengan jarak Euclid terjauh terhadap $\mathbf{x}$.

b) Menghitung $k$ local mean vectors (vektor rata-rata lokal) menggunakan $\mathrm{i}(1 \leq \mathrm{i} \leq k)$ tetangga terdekat terhadap $\mathbf{x}$ dari tiap kelas $\boldsymbol{\omega}_{j}$ berdasarkan rumus:

$$
\boldsymbol{u}_{i j}^{N N}=\frac{1}{i} \sum_{l=1}^{i} \boldsymbol{x}_{i j}^{N N}, 1 \leq i \leq k
$$

dinyatakan sebagai $\boldsymbol{U}_{j}^{N N}=\left\{\boldsymbol{u}_{i j}^{N N} \in R^{d}\right\}_{i=1}^{k}$. Jarak Euclid yang bersesuaian terhadap $\mathbf{x}$ diindikasikan sebagai himpunan: $D_{j}^{N N}=\left\{d\left(\boldsymbol{x}, \boldsymbol{u}_{1 j}^{N N}\right), d\left(\boldsymbol{x}, \boldsymbol{u}_{2 j}^{N N}\right), \ldots, d\left(\boldsymbol{x}, \boldsymbol{u}_{k j}^{N N}\right)\right\}$.

c) Menghitung $k$ generalized mean distances menggunakan $\mathrm{r}(1 \leq \mathrm{r} \leq k)$ jarak-jarak pada himpunan $D_{j}^{N N}$ untuk kelas $\boldsymbol{\omega}_{j}$. Generalized mean distance (jarak rata-rata tergeneralisasi) $r$ jarak pertama dari r pertama local mean vector terhadap $\mathbf{x}$ untuk setiap kelas dirumuskan sebagai:

$$
g\left(\boldsymbol{x}, \boldsymbol{U}_{r j}^{N N}\right)=\left(\frac{1}{r} \sum_{i=1}^{r}\left(d\left(\boldsymbol{x}, \boldsymbol{u}_{i j}^{N N}\right)\right)^{p}\right)^{\frac{1}{p}}
$$

dengan $\mathrm{j}=1,2, \ldots, \mathrm{m}$ dan $1 \leq \mathrm{r} \leq k$

dimana $\boldsymbol{U}_{r j}^{N N}=\left\{\boldsymbol{u}_{i j}^{N N} \in R^{d}\right\}_{i=1}^{r}$ dan $k$ generalized mean distances di kelas $\boldsymbol{\omega}_{j}$ dinotasikan sebagai $\boldsymbol{g}^{j}=\left\{g\left(\boldsymbol{x}, \boldsymbol{U}_{1 j}^{N N}\right), g\left(\boldsymbol{x}, \boldsymbol{U}_{2 j}^{N N}\right) \ldots g\left(\boldsymbol{x}, \boldsymbol{U}_{k j}^{N N}\right)\right\}$.

d) Menentukan sebuah nested generalized mean distance baru berdasarkan nilai $k$ generalized mean distances yang telah diperoleh sebelumnya untuk setiap kelas dengan rumus:

$$
G\left(\boldsymbol{x}, g^{j}\right)=\left(\frac{1}{k} \sum_{r=1}^{k}\left(g\left(\boldsymbol{x}, \boldsymbol{U}_{r j}^{N N}\right)\right)^{p}\right)^{\frac{1}{p}}, \mathrm{j}=1,2, \ldots, \mathrm{m} .
$$

e) Mengklasifikasikan sampel uji $\mathbf{x}$ ke dalam kelas yang memiliki nilai nested generalized mean distance yang paling minimum sebagai:

$$
\omega=\arg \min _{\omega_{j}} G\left(\boldsymbol{x}, g^{j}\right), j=1,2, \ldots, m
$$

Gou et al. (2019) menyatakan tujuan utama dari metode GMDKNN adalah mengembangkan performa klasifikasi berbasis KNN dan mengatasi sensitivitas ukuran tetangga $k$. Dalam menentukan nilai maksimal parameter $k$, Beckmann et al. (2015) mengembangkan rule of thumb pada kasus klasifikasi kelas biner sebagai berikut:

dengan nilai $n$ adalah jumlah data latih.

$$
\operatorname{Max}(k)=\operatorname{odd}(\sqrt{n})
$$

\subsection{Evaluasi Performansi Ketepatan Klasifikasi}

Data aktual dan data hasil prediksi dari model klasifikasi disajikan dengan menggunakan matriks konfusi (confusion matrix) sebagai berikut: 
keterangan:

\begin{tabular}{cccc}
\hline & \multicolumn{3}{c}{ Hasil Prediksi } \\
\cline { 2 - 4 } & Kelas & Positif & Negatif \\
\hline Data & Positif & TP & FN \\
Aktual & Negatif & FP & TN \\
\hline
\end{tabular}

TP: True Positive, data aktual positif dan diklasifikasikan positif

FP: False Positive, data aktual negatif namun diklasifikasikan positif

FN: False Negative, data aktual positif, namun diklasifikasikan negatif

TN: True Negative, data aktual negatif dan diklasifikasikan negatif

Berdasarkan nilai-nilai dalam matriks konfusi, dapat dilakukan perhitungan ukuranukuran performansi ketepatan klasifikasi yaitu Apparent Error Rate (APER), akurasi, sensitivitas, dan spesifisitas yang dirumuskan dalam Prasetyo (2014) sebagai berikut:

$$
\begin{array}{ll}
\text { APER }=\frac{(\mathrm{FP}+\mathrm{FN})}{(\mathrm{TP}+\mathrm{TN}+\mathrm{FP}+\mathrm{FN})} & \text { Sensitivitas }=\frac{\mathrm{TP}}{(\mathrm{TP}+\mathrm{FN})} \\
\text { Akurasi }=1-\mathrm{APER} & \text { Spesifisitas }=\frac{\mathrm{TN}}{(\mathrm{FP}+\mathrm{TN})}
\end{array}
$$

Evaluasi performansi klasifikasi menggunakan Geometric Mean ( $G$-Mean) dapat dirumuskan sebagai berikut (Yuchun et al., 2002):

$$
G-\text { Mean }=\sqrt{\frac{T P}{T P+F N} \times \frac{T N}{F P+T N}}
$$

Pada kasus klasifikasi kelas biner, nilai performansi klasifikasi Area under the ROC Curve (AUC) dapat didekati dengan nilai Balanced Accuracy (Bekkar et al., 2013) sebagai berikut:

$$
A U C=\frac{1}{2}(\text { sensitivity }+ \text { specitifity })
$$

\section{METODE PENELITIAN}

Data yang digunakan dalam penulisan penelitian ini adalah data sekunder, yaitu data calon debitur yang mengajukan permohonan Kredit Tanpa Agunan (KTA) ke Bank X yang terletak di Provinsi DKI Jakarta pada tahun 2018 dengan jumlah data sebanyak 23.337 data. Variabel dependen yang digunakan adalah keputusan akhir credit scoring dikelompokkan menjadi sebesar 9.832 calon debitur kredit ditolak yang dilabelkan dengan ' 1 ' dan 13.505 calon debitur kredit diterima yang dilabelkan dengan ' 0 '. Variabel independen yaitu tujuh variabel berskala numerik meliputi data usia calon debitur dalam satuan tahun, tanggungan anak dalam satuan jiwa, lama bekerja dan lama perusahaan dalam satuan tahun, pendapatan dan pinjaman yang diajukan dalam satuan rupiah, serta durasi kredit dalam satuan bulan. Software yang digunakan pada penelitian ini adalah Ms. Excel 2013, IBM SPSS Statistics 25, dan Matlab R2015a. Langkah-langkah analisis yang dilakukan pada penelitian ini sebagai berikut:

1. Melakukan seleksi fitur pada semua variabel independen (X) menggunakan uji MannWhitney pada software IBM SPSS Statistics 25.

2. Analisis data dengan metode Generalized Mean Distance-based k-Nearest Neighbor (GMDKNN) menggunakan software Matlab R2015a dengan tahapan sebagai berikut:

a. Standarisasi pada semua variabel independen $(\mathrm{X})$ menggunakan metode $z$-score.

b. Mengelompokkan data terstandarisasi ke dalam masing-masing kelas.

c. Membagi data yakni untuk data latih diambil $80 \%$ data pada masing-masing kelas dan untuk data uji diambil $20 \%$ data pada masing-masing kelas. 
d. Menghitung jarak Euclid antara data latih dan data uji.

e. Menentukan nilai parameter $k$ dan $p$.

f. Mengurutkan nilai jarak Euclid dari nilai terkecil hingga nilai terbesar.

g. Menentukan jarak terdekat sebanyak nilai $k$ yang telah ditentukan pada masingmasing kelas.

h. Menghitung $k$ local mean vectors $\boldsymbol{U}_{j}^{N N}$ dari masing-masing kelas menggunakan i (1 $\leq \mathrm{i} \leq k)$ tetangga terdekat.

i. Menghitung kembali jarak $D_{j}^{N N}$ tiap data uji terhadap setiap nilai local mean vector $\boldsymbol{u}_{i j}^{N N}$ pada $k$ local mean vectors $\boldsymbol{U}_{j}^{N N}$ untuk masing-masing kelas.

j. Menghitung $k$ generalized mean distances menggunakan $\mathrm{r}(1 \leq \mathrm{r} \leq k)$ jarak-jarak pada himpunan $D_{j}^{N N}$ untuk masing-masing kelas.

$\mathrm{k}$. Menentukan sebuah nested generalized mean distance $G$ pada masing-masing kelas berdasarkan nilai $k$ generalized mean distances.

1. Memilih kelas dengan nilai nested generalized mean distance terkecil dari setiap kelas yang ada sebagai kelas data uji.

m. Menghitung AUC hasil klasifikasi.

n. Melakukan kembali langkah e-m pada berbagai nilai parameter $k$ dan $p$ sehingga mendapatkan nilai AUC terbesar.

3. Menghitung ukuran performansi ketepatan klasifikasi berupa nilai akurasi, APER, sensitivitas, spesifisitas dan G-Mean pada model klasifikasi dengan nilai parameter $k$ dan $p$ yang menghasilkan AUC terbesar, menggunakan software Matlab R2015a.

\section{HASIL DAN PEMBAHASAN}

\subsection{Seleksi Fitur}

Dalam pengujian hipotesis Mann-Whitney, fitur yang tidak mempunyai informasi diskriminasi data terhadap kelas akan dibuang. $\mathrm{H}_{0}$ pengujian yaitu nilai rata-rata fitur dalam dua kelas keputusan akhir credit scoring sama, sedangkan $\mathrm{H}_{1}$ yaitu nilai rata-rata fitur dalam dua kelas keputusan akhir credit scoring berbeda. Dengan taraf signifikansi $\alpha=5 \%$ dan nilai $-Z_{\alpha / 2}=-1,960$, berdasarkan hasil output software SPSS diperoleh hasil uji Mann-Whitney untuk setiap variabel independen yang dinyatakan dalam tabel sebagai berikut:

Tabel 1. Uji Mann-Whitney

\begin{tabular}{cccc}
\hline Variabel & $\mathbf{Z}_{\text {hitung }}$ & Sig. & Keputusan \\
\hline Usia & $-21,744$ & 0,000 & $\mathrm{H}_{0}$ ditolak \\
Tanggungan Anak & $-12,849$ & 0,000 & $\mathrm{H}_{0}$ ditolak \\
Lama Bekerja & $-12,767$ & 0,000 & $\mathrm{H}_{0}$ ditolak \\
Lama Perusahaan & $-7,112$ & 0,000 & $\mathrm{H}_{0}$ ditolak \\
Pendapatan & $-38,867$ & 0,000 & $\mathrm{H}_{0}$ ditolak \\
Pinjaman yang Diajukan & $-27,500$ & 0,000 & $\mathrm{H}_{0}$ ditolak \\
Durasi Kredit & $-16,550$ & 0,000 & $\mathrm{H}_{0}$ ditolak \\
\hline
\end{tabular}

Berdasarkan tabel di atas, dapat disimpulkan bahwa semua variabel independen memiliki nilai rata-rata fitur dalam dua kelas keputusan akhir credit scoring yang berbeda, sehingga semua variabel independen berpengaruh secara signifikan terhadap keputusan akhir credit scoring dan valid untuk dimasukkan dalam model klasifikasi.

\subsection{Standarisasi Data}

Sebelum dilakukan standarisasi, data terlebih dahulu dibagi menjadi data latih dengan proporsi sebesar $80 \%$ yaitu sebanyak 18.670 data dan data uji dengan proporsi sebesar $20 \%$ 
yaitu sebanyak 4.667 data. Hasil standarisasi metode $z$-score tujuh variabel independen dari seluruhnya 18.670 data latih dinyatatakan dalam tabel sebagai berikut:

Tabel 2. Data Latih Setelah Distandarisasi

\begin{tabular}{|c|c|c|c|c|c|c|c|c|}
\hline No & Usia & $\begin{array}{c}\text { Tanggungan } \\
\text { Anak }\end{array}$ & $\begin{array}{c}\text { Lama } \\
\text { Bekerja }\end{array}$ & $\begin{array}{c}\text { Lama } \\
\text { Perusahaan }\end{array}$ & Pendapatan & $\begin{array}{c}\text { Pinjaman } \\
\text { yang } \\
\text { Diajukan }\end{array}$ & $\begin{array}{c}\text { Durasi } \\
\text { Kredit }\end{array}$ & $\begin{array}{c}\text { Keputusan } \\
\text { Akhir }\end{array}$ \\
\hline 1 & $-0,9293$ & $-1,2791$ & $-0,5582$ & $-0,4734$ & 0,2513 & $-0,2388$ & $-1,2160$ & 0 \\
\hline 2 & $-0,7010$ & 0,2264 & $-0,7936$ & 0,1095 & $-0,0793$ & 0,1626 & 0,3544 & 0 \\
\hline 3 & $-0,0160$ & 2,4848 & 0,5011 & $-0,1554$ & 0,7644 & 0,5479 & 0,3544 & 0 \\
\hline 4 & 1,0114 & 1,7320 & 1,3250 & 1,5403 & $-0,1403$ & $-0,4796$ & $-0,6925$ & 0 \\
\hline 5 & 0,6689 & 2,4848 & $-0,9113$ & 1,9112 & 1,0653 & 2,1693 & 0,3544 & 0 \\
\hline$\ldots$ & $\ldots$ & $\ldots$ & $\ldots$ & $\ldots$ & $\ldots$ & $\ldots$ & $\ldots$ & $\ldots$ \\
\hline 18669 & $-1,3860$ & $-1,2791$ & $-0,7936$ & $-0,8443$ & $-0,6738$ & $-0,2388$ & 0,3544 & 1 \\
\hline 18670 & $-1,5001$ & $-0,5263$ & $-1,0290$ & $-0,8443$ & $-0,5405$ & $-0,2388$ & 0,3544 & 1 \\
\hline
\end{tabular}

Sedangkan hasil standarisasi metode z-score tujuh variabel independen dari seluruhnya 4.667 data uji dinyatatakan dalam tabel sebagai berikut:

Tabel 3. Data Uji Setelah Distandarisasi

\begin{tabular}{|c|c|c|c|c|c|c|c|c|}
\hline No & Usia & $\begin{array}{c}\text { Tanggungan } \\
\text { Anak }\end{array}$ & $\begin{array}{c}\text { Lama } \\
\text { Bekerja }\end{array}$ & $\begin{array}{c}\text { Lama } \\
\text { Perusahaan }\end{array}$ & Pendapatan & $\begin{array}{c}\text { Pinjaman } \\
\text { yang } \\
\text { Diajukan }\end{array}$ & $\begin{array}{c}\text { Durasi } \\
\text { Kredit }\end{array}$ & $\begin{array}{c}\text { Keputusan } \\
\text { Akhir }\end{array}$ \\
\hline 1 & 0,7831 & 1,7320 & 0,0303 & $-1,1622$ & $-0,4540$ & $-0,5598$ & $-0,1691$ & 0 \\
\hline 2 & $-0,0160$ & 0,2264 & $-0,3228$ & $-0,6853$ & $-0,6256$ & $-0,6401$ & $-1,2160$ & 0 \\
\hline 3 & 0,4406 & $-0,5263$ & $-1,0290$ & $-0,3674$ & $-0,5998$ & $-0,6401$ & $-0,1691$ & 0 \\
\hline 4 & $-0,1302$ & 0,2264 & 0,5011 & $-0,7913$ & $-0,2621$ & 0,0823 & 0,3544 & 0 \\
\hline 5 & $-0,2444$ & 0,2264 & $-1,0290$ & $-1,3212$ & 0,1881 & $-0,2388$ & $-1,2160$ & 0 \\
\hline$\ldots$ & $\ldots$ & $\ldots$ & $\ldots$ & $\ldots$ & $\ldots$ & $\ldots$ & $\ldots$ & $\ldots$ \\
\hline 4666 & $-1,1576$ & $-1,2791$ & $-1,1467$ & 0,5864 & $-0,4676$ & $-0,3993$ & 0,3544 & 1 \\
\hline 4667 & 2,0388 & 0,9792 & 2,3843 & 0,8514 & $-0,3243$ & $-0,3993$ & $-1,7394$ & 1 \\
\hline
\end{tabular}

\subsection{Penentuan Klasifikasi Kelas untuk Observasi Terakhir Data Uji}

Pada tahap ini akan digunakan metode Generalized Mean Distance-Based k-Nearest Neighbor (GMDKNN) untuk mengklasifikasikan kelas dari seluruh data uji, dan sebagai ilustrasi perhitungan digunakan data uji terakhir yaitu data uji ke-4.667. Sebelum melakukan metode klasifikasi, terlebih dahulu data latih dibagi berdasarkan label kelasnya yaitu data latih kelas diterima atau kelas 1 dengan jumlah 10.804 data dan data latih kelas ditolak atau kelas 2 dengan jumlah 7.866 data.

\subsubsection{Perhitungan Jarak Euclid}

Hasil perhitungan jarak Euclid untuk data uji ke-4667 terhadap seluruh data latih dapat ditampilkan dalam tabel berikut:

Tabel 4. Perhitungan Jarak Euclid untuk Data Uji Ke-4.667 


\subsubsection{Penentuan Parameter Model Klasifikasi}

\begin{tabular}{|c|c|c|c|c|c|c|c|c|c|}
\hline No & Usia & $\begin{array}{c}\text { Tanggungan } \\
\text { Anak }\end{array}$ & $\begin{array}{c}\text { Lama } \\
\text { Bekerja }\end{array}$ & $\begin{array}{c}\text { Lama } \\
\text { Perusahaan }\end{array}$ & Pendapatan & $\begin{array}{c}\text { Pinjaman } \\
\text { yang } \\
\text { Diajukan }\end{array}$ & $\begin{array}{c}\text { Durasi } \\
\text { Kredit }\end{array}$ & $\begin{array}{c}\text { Keputusan } \\
\text { Akhir }\end{array}$ & $\begin{array}{c}\text { Jarak } \\
\text { Euclid }\end{array}$ \\
\hline 1 & $-0,9293$ & $-1,2791$ & $-0,5582$ & $-0,4734$ & 0,2575 & $-0,2388$ & $-1,2160$ & 0 & 4,9954 \\
\hline 2 & $-0,7010$ & 0,2264 & $-0,7936$ & 0,1095 & $-0,0705$ & 0,1626 & 0,3544 & 0 & 4,8459 \\
\hline 3 & $-0,0160$ & 2,4848 & 0,5011 & $-0,1554$ & 0,7667 & 0,5479 & 0,3544 & 0 & 4,1852 \\
\hline$\ldots$ & $\ldots$ & $\ldots$ & $\ldots$ & $\ldots$ & $\ldots$ & $\ldots$ & $\ldots$ & $\ldots$ & $\ldots$ \\
\hline 18669 & $-1,3860$ & $-1,2791$ & $-0,7936$ & $-0,8443$ & $-0,6604$ & $-0,2388$ & 0,3544 & 1 & 5,8597 \\
\hline 18670 & $-1,5001$ & $-0,5263$ & $-1,0290$ & $-0,8443$ & $-0,5281$ & $-0,2388$ & 0,3544 & 1 & 5,8115 \\
\hline
\end{tabular}

Pada penelitian ini dengan jumlah data latih sebesar 18.670 diperoleh nilai $k$ maksimal sebesar 137. Nilai-nilai parameter $k$ yang diujicobakan yaitu:

$\{1,3,5,7,9,11,13,15,17,27,37,57,77,107,137\}$. Berdasarkan penelitian Gou et al. (2019), maka nilai-nilai parameter $p$ yang diujicobakan pada penelitian ini yaitu: $\{-13,-11,-9,-7,-5,-4,-3,-2,-1,1,2,3\}$. Dengan bantuan program MatLab, diperoleh hasil nilai AUC untuk berbagai nilai parameter $k$ dan $p$ yang dapat dilihat pada Tabel sebagai berikut:

Tabel 5. Hasil Nilai AUC GMDKNN

\begin{tabular}{|c|c|c|c|c|c|c|c|c|c|c|c|c|}
\hline Nilai $k$ & -13 & -11 & -9 & -7 & -5 & -4 & -3 & -2 & -1 & 1 & 2 & 3 \\
\hline 1 & 0,6585 & 0,6585 & 0,6585 & 0,6585 & 0,6585 & 0,6585 & 0,6585 & 0,6585 & 0,6585 & 0,6585 & 0,6585 & 0,6585 \\
\hline 3 & 0,6736 & 0,6745 & 0,6750 & 0,6757 & 0,6753 & 0,6766 & 0,6764 & 0,6752 & 0,6751 & 0,6756 & 0,6729 & 0,6742 \\
\hline 5 & 0,6825 & 0,6826 & 0,6830 & 0,6845 & 0,6816 & 0,6785 & 0,6799 & 0,6818 & 0,6821 & 0,6782 & 0,6775 & 0,6750 \\
\hline 7 & 0,6851 & 0,6853 & 0,6866 & 0,6879 & 0,6893 & 0,6880 & 0,6878 & 0,6891 & 0,6868 & 0,6844 & 0,6852 & 0,6829 \\
\hline 9 & 0,6875 & 0,6876 & 0,6884 & 0,6929 & 0,6929 & 0,6921 & 0,6929 & 0,6898 & 0,6891 & 0,6863 & 0,6894 & 0,6869 \\
\hline 11 & 0,6874 & 0,6900 & 0,6922 & $\mathbf{0 , 6 9 3 3}$ & 0,6921 & 0,6933 & 0,6931 & 0,6895 & 0,6899 & 0,6882 & 0,6895 & 0,6891 \\
\hline 13 & 0,6894 & 0,6896 & 0,6907 & 0,6931 & 0,6959 & 0,6963 & 0,6936 & 0,6914 & 0,6913 & 0,6886 & 0,6891 & 0,6876 \\
\hline 15 & 0,6903 & 0,6915 & 0,6916 & 0,6933 & 0,6958 & 0,6974 & 0,6935 & 0,6926 & 0,6923 & 0,6933 & 0,6895 & 0,6906 \\
\hline 17 & 0,6915 & 0,6939 & 0,6925 & 0,6914 & 0,6949 & 0,6965 & 0,6965 & 0,6947 & 0,6947 & 0,6950 & 0,6922 & 0,6908 \\
\hline 27 & 0,6955 & 0,6961 & 0,6971 & 0,6971 & 0,7001 & 0,6996 & 0,6989 & 0,7009 & 0,7021 & 0,7001 & 0,7011 & 0,7020 \\
\hline 37 & 0,6961 & 0,6962 & 0,6987 & 0,6989 & 0,6999 & 0,7021 & 0,7020 & 0,7019 & 0,7030 & 0,7053 & 0,7049 & 0,7054 \\
\hline 57 & 0,6978 & 0,6982 & 0,7001 & 0,6996 & 0,7005 & 0,7031 & 0,7053 & 0,7047 & 0,7080 & 0,7124 & $\mathbf{0 , 7 1 3 2}$ & 0,7113 \\
\hline 77 & 0,6993 & 0,6995 & 0,7026 & 0,7018 & 0,7049 & 0,7074 & 0,7109 & 0,7130 & 0,7169 & 0,7164 & 0,7148 & 0,7150 \\
\hline 107 & 0,7016 & 0,7022 & 0,7038 & 0,7052 & 0,7100 & 0,7126 & 0,7169 & 0,7196 & 0,7197 & 0,7214 & 0,7180 & 0,7172 \\
\hline 137 & 0,7015 & 0,7039 & 0,7051 & 0,7061 & 0,7135 & 0,7164 & 0,7195 & 0,7223 & $\mathbf{0 , 7 2 3 8}$ & 0,7196 & 0,7178 & 0,7177 \\
\hline
\end{tabular}

Dengan memperhatikan parameter yang menghasilkan nilai AUC terbesar, maka pada penelitian ini model klasifikasi GMDKNN dibangun dengan menggunakan nilai parameter $k$ yaitu $k=137$ dan nilai parameter $p$ yaitu $p=-1$. Tingginya nilai parameter $k$ ini menunjukkan bahwa model klasifikasi dapat lebih banyak memperhitungkan tetangga terdekat, serta mampu mengatasi sensitivitas terhadap tetangga terdekat ukuran $k$. Selain itu, berdasarkan nilai AUC juga ditunjukkan bahwa performa klasifikasi yang optimal cenderung dihasilkan oleh parameter $p$ yang bernilai negatif. 


\subsubsection{Multi Local Mean Vectors}

Setelah sebelumnya dihitung jarak Euclid untuk semua data latih, selanjutnya pada masing-masing kelas ditentukan $k$ tetangga terdekat yaitu 137 tetangga terdekat berdasarkan kedekatan jarak Euclid. Dari 137 tetangga terdekat ini, pada masing-masing kelas kemudian dihitung nilai multi local mean vectors atau $k$ local mean vectors menggunakan i tetangga terdekat dari tiap kelas, dimana i bernilai $1 \leq \mathrm{i} \leq k$ atau i bernilai 1 hingga 137 sehingga diperoleh hasil perhitungan sejumlah 137 local mean vectors untuk masing-masing kelas 1 dan kelas 2. Setelah diperoleh nilai multi local mean vectors, kemudian dihitung kembali jarak Euclid antara multi local mean vectors terhadap data uji. Hasil perhitungan multi local mean vectors beserta jarak Euclid nya pada kelas 1 dapat ditampilkan pada Tabel sebagai berikut:

Tabel 6. Multi Local Mean Vectors Kelas 1 Beserta Jarak Euclid nya

\begin{tabular}{|c|c|c|c|c|c|c|c|c|}
\hline No & Usia & $\begin{array}{c}\text { Jumlah } \\
\text { Tanggungan } \\
\text { Anak }\end{array}$ & $\begin{array}{c}\text { Lama } \\
\text { Bekerja }\end{array}$ & $\begin{array}{c}\text { Lama } \\
\text { Perusahaan }\end{array}$ & Pendapatan & $\begin{array}{c}\text { Pinjaman } \\
\text { yang } \\
\text { Diajukan }\end{array}$ & $\begin{array}{c}\text { Durasi } \\
\text { Kredit }\end{array}$ & $\begin{array}{c}\text { Jarak } \\
\text { Euclid }\end{array}$ \\
\hline 1 & 1,9247 & 0,9792 & 2,2666 & 0,8514 & 0,0079 & $-0,3993$ & $-1,2160$ & 0,6413 \\
\hline 2 & 2,0388 & 0,9792 & 2,3255 & 0,8514 & 0,0381 & $-0,3190$ & $-1,2160$ & 0,6444 \\
\hline 3 & 1,9627 & 0,9792 & 2,2666 & 0,8514 & $-0,1003$ & $-0,4528$ & $-1,2160$ & 0,5888 \\
\hline. & $\ldots$ & $\ldots$ & $\ldots$ & $\ldots$ & $\ldots$ & $\ldots$ & $\ldots$ & $\ldots$ \\
\hline 136 & 1,7786 & 0,7910 & 2,1048 & 0,7228 & 0,0199 & $-0,4385$ & $-1,0531$ & 0,8882 \\
\hline 137 & 1,7805 & 0,7924 & 2,1051 & 0,7122 & 0,0168 & $-0,4404$ & $-1,0581$ & 0,8839 \\
\hline
\end{tabular}

Hasil perhitungan multi local mean vectors beserta jarak Euclid nya pada kelas 2 dapat ditampilkan pada Tabel sebagai berikut:

Tabel 7. Multi Local Mean Vectors Kelas 2 Beserta Jarak Euclid nya

\begin{tabular}{|c|c|c|c|c|c|c|c|c|}
\hline No & Usia & $\begin{array}{c}\text { Jumlah } \\
\text { Tanggungan } \\
\text { Anak }\end{array}$ & $\begin{array}{c}\text { Lama } \\
\text { Bekerja }\end{array}$ & $\begin{array}{c}\text { Lama } \\
\text { Perusahaan }\end{array}$ & Pendapatan & $\begin{array}{c}\text { Pinjaman } \\
\text { yang } \\
\text { Diajukan }\end{array}$ & $\begin{array}{c}\text { Durasi } \\
\text { Kredit }\end{array}$ & $\begin{array}{c}\text { Jarak } \\
\text { Euclid }\end{array}$ \\
\hline 1 & 2,0388 & 0,9792 & 2,1489 & 0,9044 & $-0,1460$ & $-0,8006$ & $-1,7394$ & 0,5011 \\
\hline 2 & 2,0388 & 0,9792 & 2,2078 & 0,8779 & $-0,1836$ & $-0,7605$ & $-1,4777$ & 0,5006 \\
\hline 3 & 2,0388 & 0,9792 & 2,4236 & 1,0457 & $-0,2909$ & $-0,6401$ & $-1,5650$ & 0,3589 \\
\hline. & $\ldots$ & $\ldots$ & $\ldots$ & $\ldots$ & $\ldots$ & $\ldots$ & $\ldots$ & $\ldots$ \\
\hline 136 & 1,7660 & 0,8353 & 2,1368 & 0,7131 & $-0,1923$ & $-0,4687$ & $-1,1159$ & 0,7659 \\
\hline 137 & 1,7672 & 0,8418 & 2,1352 & 0,7064 & $-0,1912$ & $-0,4670$ & $-1,1167$ & 0,7655 \\
\hline
\end{tabular}

\subsubsection{Multi Generalized Mean Distances}

Multi generalized mean distances pada tiap kelas, diperoleh dengan menghitung generalized mean atau power mean dari 1 jarak Euclid pertama, 2 jarak Euclid pertama, 3 jarak Euclid pertama, seterusnya hingga 137 jarak Euclid antara data uji ke-4.667 dengan multi local mean vectors. Dari hasil perhitungan ini kemudian pada masing-masing kelas diperoleh 137 generalized mean distances untuk parameter $p=-1$. Berdasarkan hasil perhitungan, multi generalized mean distances 137 tetangga terdekat di kelas 1 dapat dinyatakan sebagai berikut:

$\boldsymbol{g}^{1}=\left\{g\left(\boldsymbol{x}, \boldsymbol{U}_{11}^{N N}\right), g\left(\boldsymbol{x}, \boldsymbol{U}_{21}^{N N}\right), g\left(\boldsymbol{x}, \boldsymbol{U}_{31}^{N N}\right) \ldots g\left(\boldsymbol{x}, \boldsymbol{U}_{1371}^{N N}\right)\right\}$

$\boldsymbol{g}^{1}=\{0,6413 ; 0,6428 ; 0,6237 ; \ldots 0,7396\}$ 
adapun multi generalized mean distances 137 tetangga terdekat di kelas 2 dapat dinyatakan sebagai berikut:

$\boldsymbol{g}^{2}=\left\{g\left(\boldsymbol{x}, \boldsymbol{U}_{12}^{N N}\right), g\left(\boldsymbol{x}, \boldsymbol{U}_{22}^{N N}\right), g\left(\boldsymbol{x}, \boldsymbol{U}_{32}^{N N}\right) \ldots g\left(\boldsymbol{x}, \boldsymbol{U}_{1372}^{N N}\right)\right\}$

$\boldsymbol{g}^{2}=\{0,5011 ; 0,5009 ; 0,4425 ; \ldots 0,5196\}$

\subsubsection{Nested Generalized Mean Distance}

Nilai nested generalized mean distance pada tiap kelas diperoleh dengan menghitung generalized mean dari seluruh nilai generalized mean distances pada multi generalized mean distances untuk tiap kelas. Dengan bantuan aplikasi MatLab diperoleh nilai nested generalized mean distance pada kelas 1 dan kelas 2, dimana pada kelas 1 hasil perhitungannya adalah sebagai berikut:

$G\left(\boldsymbol{x}, g^{1}\right)=\left(\frac{1}{137} \sum_{r=1}^{137}\left(g\left(\boldsymbol{x}, \boldsymbol{U}_{r 1}^{N N}\right)\right)^{-1}\right)^{\frac{1}{-1}}=0,6750$

adapun pada kelas 2 diperoleh hasil perhitungan nilai nested generalized mean distance sebagai berikut:

$G\left(\boldsymbol{x}, g^{2}\right)=\left(\frac{1}{137} \sum_{r=1}^{137}\left(g\left(\boldsymbol{x}, \boldsymbol{U}_{r 2}^{N N}\right)\right)^{-1}\right)^{\frac{1}{-1}}=0,4383$

Pada perhitungan ini nilai nested generalized mean distance pada kelas 2 adalah $G\left(\boldsymbol{x}, g^{2}\right)=0,4383$ memiliki nilai yang lebih kecil dibandingkan nilai nested generalized mean distance pada kelas 1 adalah $G\left(x, g^{1}\right)=0,6750$, dengan demikian menggunakan metode klasifikasi GMDKNN data uji ke-4.667 yang merupakan data uji terakhir diklasifikasikan ke dalam kelas 2 atau kelas dengan label 1 yaitu kelas kategori keputusan akhir credit scoring ditolak.

\subsection{Evaluasi Performansi Ketepatan Klasifikasi}

Berdasarkan perhitungan yang telah dilakukan, hasil klasifikasi menggunakan metode GMDKNN dapat dilihat pada tabel Matriks Konfusi berikut:

Tabel 8. Matriks Konfusi Metode GMDKNN

\begin{tabular}{ccc}
\hline Hasil Observasi & \multicolumn{2}{c}{ Hasil Prediksi (Predicted Class) } \\
\cline { 2 - 3 } (Actual Class) & Kelas 2 (Ditolak) & Kelas 1 (Diterima) \\
\hline Kelas 2 (Ditolak) & 1.196 & 770 \\
\hline Kelas 1 (Diterima) & 434 & 2.267 \\
\hline
\end{tabular}

Berdasarkan nilai matriks konfusi pada Tabel 8, klasifikasi memiliki ukuran kinerja sistem yang dinyatakan dengan nilai APER $=0,2580$, akurasi $=74,20 \%$, sensitivitas $=0,6083$, spesifisitas $=0,8393$, AUC $=0,7238$, dan $G$-Mean $=0,7146$. Dengan nilai AUC $=0,7238$ maka model klasifikasi berada dalam kategori Good dengan kata lain model klasifikasi metode GMDKNN merupakan model klasifikasi yang baik untuk diterapkan pada kasus klasifikasi keputusan akhir permohonan kredit calon debitur Kredit Tanpa Agunan (KTA) pada proses credit scoring Bank X di Provinsi DKI Jakarta.

\section{KESIMPULAN}


Metode GMDKNN dapat diterapkan dalam mengklasifikasikan keputusan akhir permohonan kredit calon debitur KTA pada proses credit scoring Bank X di Provinsi DKI Jakarta. Melalui seleksi fitur uji Mann-Whitney, variabel usia, tanggungan anak, lama bekerja, lama perusahaan, pendapatan, pinjaman yang diajukan, dan durasi kredit valid untuk dimasukkan dalam model klasifikasi. Parameter $k$ dan $p$ yang memberikan model klasifikasi dengan performansi ketepatan klasifikasi terbaik berdasarkan percobaan dengan cara trial error adalah $k=137$ dan $p=-1$. Dalam penelitian ini diperoleh ukuran kinerja sistem klasifikasi yang dinyatakan dengan nilai APER $=0,2580$, akurasi $=74,20 \%$, sensitivitas $=0,6083$, spesifisitas $=0,8393$, AUC $=0,7238$, dan $G$-Mean $=0,7146$. Dengan nilai AUC $=0,7238$ maka model klasifikasi metode GMDKNN merupakan model klasifikasi yang baik untuk diterapkan pada kasus klasifikasi keputusan akhir permohonan kredit calon debitur KTA pada proses credit scoring Bank X di Provinsi DKI Jakarta.

\section{DAFTAR PUSTAKA}

Beckmann, M., Ebecken, N. F. F., Lima B. S. L. 2015. A KNN Undersampling Approach for Data Balancing. Journal of Intelligent Learning Systems and Applications Vol. 7: Hal. 104-116.

Bekkar, M., Djemma, H. K., \& Alitouche, T. A. 2013. Evaluation Measures for Models Asessment Over Imbalanced Data Sets. Journal of Information Engineering and Applications Vol. 3, No. 10.

Conover, W. J. 1980. Practical Nonparametric Statistics. 2 ed. New York: John Wiley and Sons, Inc.

Daniel, W. W. 1989. Statistika Nonparametrik Terapan. Diterjemahkan oleh: Alex Tri Kantjono W. Jakarta: PT Gramedia. Terjemahan dari: Applied Nonparametric Statistics

Fensterstock, A. 2005. Credit Scoring and the Next Step. Business Credit Vol. 107, No. 3 : Hal. 46-49.

Firdaus, R., \& Ariyanti, M. 2009. Manajemen Perkreditan Bank Umum. Bandung : Alfabeta.

Gou, J., Ma, H., Ou, W., Zeng, S., Rao, Y., \& Yang, H. 2019. A Generalized Mean Distancebased $k$-Nearest Neighbor Classifier. Expert Systems With Applications Vol. 115: Hal. 356-372.

Han, J., \& Kamber, M. 2006. Data Mining : Concept and Techniques, Second Edition. London : Morgan Kaufmann Publishers.

Johnson, R. A., Winchern, D.W. 2007. Applied Multivariate Statistical Analysis. Sixth Edition. New Jersey: Prentice Hall International. Inc.

Larose, D. T. 2005. Discovering Knowledge in Data: An Introduction to Data Mining. New Jersey : John Wiley \& Sons, Inc.

Morrison, J. 2004. Introduction to Survival Analysis in Business. The Journal of Business Forecasting Methods \& Systems Vol. 23, No. 1: Hal. 18-22.

Prasetyo, E. 2014. Data Mining Mengolah Data Menjadi Informasi Menggunakan Matlab. Yogyakarta : ANDI.

Rama, D. V., \& Jones, F. L. 2009. Sisitem Informasi Akuntansi. Jakarta : Salemba Empat.

Republik Indonesia. 1998. Undang-Undang No. 10 Tahun 1998 tentang Perbankan. Lembaran Negara Tahun 1998. Sekretariat Negara. Jakarta.

Sinungan, M. 1991. Dasar-Dasar dan Teknik Managemen Kredit. Jakarta : Bumi Aksara.

Turban, E., Aronson, J. E., Liang, T. 2005. Decision Support Systems and Intelligent Systems. New Jersey : Prentice-Hall, Inc.

Yuchun, T., Ya-Qing, Z., Chawla, N. V., \& Sven, K. 2002. SVMs Modeling for Highly Imbalanced Classification. Journal of Latex Class Files Vol. 1, No. 11. 
